

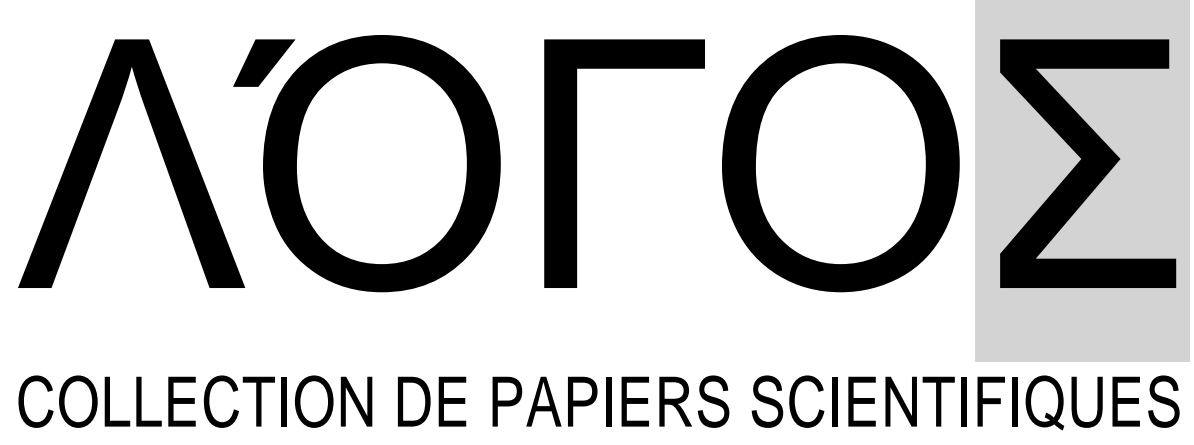

SUR LES MATÉRIAUX DE LA CONFÉRENCE SCIENTIFIQUE ET PRATIQUE INTERNATIONALE

«TENDANCES SCIENTIFIQUES DE LA RECHERCHE FONDAMENTALE ET APPLIQUÉE» 30 OCTOBRE 2020

\section{VOLUME 2}

Strasbourg • République française 
Président du comité d'organisation: Holdenblat $M$.

Responsable de la mise en page: Bilous $T$.

Responsable de la conception: Bondarenko I.

\section{T 35 Tendances scientifiques de la recherche fondamentale et} appliquée: collection de papiers scientifiques «^ОГО $\Sigma$ » avec des matériaux de la conférence scientifique et pratique internationale (Vol. 2), 30 octobre, 2020. Strasbourg, République française: Plateforme scientifique européenne.

ISBN 978-2-37467-128-4 («La Fedeltà», République française)

DOI 10.36074/30.10.2020.v2

Les résumés et articles des participants à la conférence multidisciplinaire scientifique et pratique internationale "Tendances scientifiques de la recherche fondamentale et appliquée», qui s'est tenue à Strasbourg le 30 octobre 2020, sont présentés.

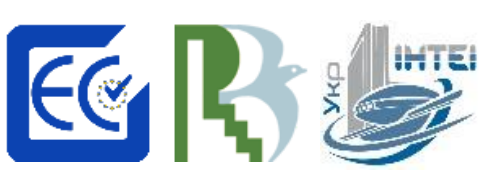

La conférence est incluse dans le catalogue des conférences scientifiques internationales; approuvé par ResearchBib et UKRISTEI (Certificat № 450 du 05/10/2020); est certifié par Euro Science Certification Group (Certificat № 22182 du 04/10/2020).

Le matériel de la conférence sera accessible au public selon les termes de la licence Creative Commons Attribution 4.0 International (CC BY 4.0).

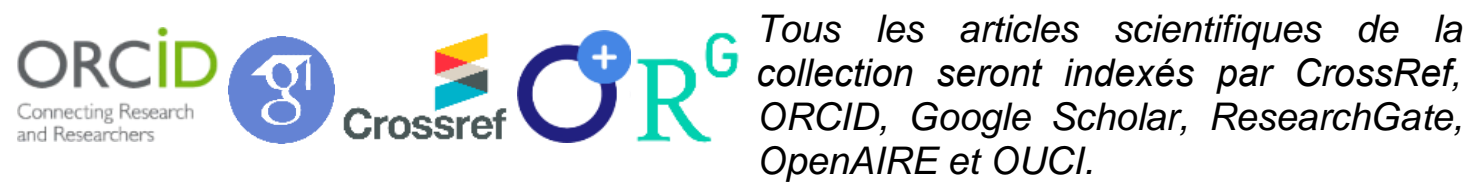

UDC $001(08)$

(C) Le collectif des participants à la conférence, 2020

(C) Collection de papiers scientifiques «^ОГОО $», 2020$ 


\section{CONTENU}

\section{SECTION VII. SCIENCES CHIMIQUES}

ОТРИМАННЯ ЦИНК(ІІ) ОКСИДУ МЕТОДОМ ОСАДЖЕННЯ

Гуцул X.P. .7

\section{SECTION VIII.}

\section{SCIENCES BIOLOGIQUES}

АНАЛІЗ ВИДІВ РОДИНИ RANUNCULACEAE JUSS ФЛОРИ НАЦІОНАЛЬНОГО ПРИРОДНОГО ПАРКУ ОЛЕШКІВСЬКІ ПІСКИ» (ХЕРСОНСЬКА ОБЛАСТЬ, УКРАЇНА)

Науково-дослідна група:

Мельник Р.П., Непрокін А.В., Ложкіна О.І., Конюшенко І.П. .10

КОМБІНАЦІЙНА ЗДАТНІСТЬ БАТЬКІВСЬКИХ ФОРМ ТЮТЮНУ ЗА ОСНОВНИМИ ОЗНАКАМИ ТА ЇХ КЛАСИФІКАЦІЯ

Глюдзик-Шемота М.Ю.

ОСОБЛИВОСТІ ТЕРМОРЕГУЛЯЦІЇ ОРГАНІЗМУ ЛЮДИНИ В УМОВАХ ПОМІРНОГО КЛІМАТУ

Невмержицький В.В.

ХАРАКТЕРИСТИКА КІЛЬКОСТІ ДІАПАУЗНИХ ЛИЧИНОК ТА ЛЯЛЕЧОК КАШТАНОВОÏ МІНУЮЧОÏ МОЛІ (CAMERARIA OHRIDELLA DESCHKA) У РІЗНИХ МІСЦЯХ М. КАУНАСА (ЛИТВА)

Кичак О.О., Кавун Е.М.

\section{SECTION IX.}

\section{SCIENCES MÉDICALES}

APPARTENANCE AUX TYPOLOGIES HUMAINES CONTRIBUE-T-IL AUX CARACTÉRISTIQUES DU SYNDROME MÉTABOLIQUE?

Tkachenko E., Prilutsky M., Moulim M.

AUTOIMMUNE THYROIDITIS IN PATIENTS WITH CHRONIC HEPATITIS C Nevkhoroshev Y., Tkemaladze D.

COMPARATIVE ASSESSMENT OF THE STUDENTS ATTENTION LEVEL DURING FACE-TO-FACE AND DISTANCE CLASSES

Research group

Kadnai O.S., Mozgova T.P., Leshchyna I.V., Fedorchenko S.V.

RELATIONSHIP BETWEEN FAMILIES OF PATIENTS WITH DEMENTIA TO DIAGNOSIS AND TREATMENT

Kozhyna H.M., Zelenska K.O., Kaploukh O.M. 
4 - Tendances scientifiques de la recherche fondamentale et appliquée • Volume 2

THE DEGREE OF NERVOUS AND MENTAL STRESS AND ANXIETY IN INTERNALLY DISPLACED PERSONS (IDPED) AND RESIDENTS OF THE KHARKIV REGION

Research group:

Kozhyna H.M., Zelenska K.O., Kraskovska T.Y., Zelenska H.M. 32

ДИФЕРЕНЦІЙНІ ЗМІНИ СТОМАТОЛОГІЧНОГО СТАТУСУ У ВІКОВОМУ АСПЕКТІ

Стецик М.О., Стецик А.О., Костенко С.Б.

ДОСЛІДЖЕННЯ ЯКОСТІ СНУ СТУДЕНТІВ-МЕДИКІВ

Гармаш І.В., Дегтяр К.О.

ОСОБЛИВОСТІ РЕНТГЕНОДІАГНОСТИКИ ХІЛОТОРАКСУ

Гуманець К.Р., Марченко І.О.

ПСИХОГІГІЕНА, ЯК РОЗДІЛ НАУКИ НАЦІЛЕНИЙ НА ПОПЕРЕДЖЕННЯ ВИНИКНЕННЯ ДЕПРЕСІЇ, ІПОХОНДРІЇ ТА АСТЕНІЇ

Тереник С.А., Старусева В.В.

\section{SECTION X.}

VÉTÉRINAIRE

ВПРОВАДЖЕННЯ ІНТЕРАКТИВНИХ ТЕХНОЛОГІЙ ПРИ ВИКЛАДАННІ ФАРМАКОЛОГІЇ У ПРОЦЕСІ ПІДГОТОВКИ МАЙБУТНІХ ФАХІВЦІВ ВЕТЕРИНАРНОї МЕДИЦИНИ

Жванія О.І.

\section{SECTION XI.}

PSYCHOLOGIE ET SOCIOLOGIE

БАГАТОРІВНЕВИЙ ПІДХІД В ЛІКУВАННІ ХВОРИХ ІЗ СИНДРОМОМ АЛКОГОЛЬНОЇ ЗАЛЕЖНОСТІ

Науково-дослідна група:

Харківська А.І., Уніченко А.В., Чухраєва О.М., Мельник А.Ю. .48

ГЕНДЕРНЫЕ РОЛИ СЕМЬИ КАК БАРЬЕР В РАЗВИТИИ ИНДИВИДУАЛЬНОСТИ

Бугачевская Е.В.

\section{SECTION XII.}

\section{COMMUNICATIONS SOCIALES ET CULTUROLOGIE}

ПРОБЛЕМА ВПРОВАДЖЕННЯ ЕЛЕКТРОННОГО ДОКУМЕНТООБІГУ В РОБОТУ СЛУЖБ ДОКУМЕНТАЦІЙНОГО ЗАБЕЗПЕЧЕННЯ УПРАВЛІННЯ Курило Н.О. 


\title{
DOI 10.36074/30.10.2020.v2.09 \\ RELATIONSHIP BETWEEN FAMILIES OF PATIENTS WITH DEMENTIA TO DIAGNOSIS AND TREATMENT
}

\author{
Hanna Kozhyna \\ Doctor of Medical Sciences, Professor, Head of the Department of Psychiatry, \\ Narcology, Medical Psychology and Social Work \\ Kharkiv National Medical University \\ Kateryna Zelenska \\ Candidate of Medical Sciences, \\ Associate Professor of the Department of Psychiatry, Narcology, \\ Medical Psychology and Social Work \\ Kharkiv National Medical University \\ Olha Kaploukh \\ Postgraduate Students of the Department of Psychiatry, Narcology, \\ Medical Psychology and Social Work \\ Kharkiv National Medical University
}

UKRAINE

Relevance: Vascular dementia occurs in the elderly - a mental illness in the process of which the that impares patient's cognitive and mental abilities due to existing somatic diseases that disrupt the integrity of the vascular wall and its permeability. Dementia causes a deterioration in mental abilities, memory, the ability to recognize people and objects, as well as the ability to navigate in time and space, the ability to perform daily activities and communicate with others is gradually reduced. Among other things, the patient suffers from disturbances of consciousness, anger, suspicion and outbreaks of aggression may also occur. This condition limits the abilities of the elderly. Dementia is considered one of the most serious mental illnesses not only for the patient, but also for his family and society [1, 2].

Objective: to determine the attitude of the families of patients with dementia to the diagnosis and treatment in a psychiatric hospital.

Materials and methods: 63 families were diagnosed: 63 patients with dementia who were treated at the Regional Clinical Psychiatric Hospital №3 and 61 members of their families. During the study, we used the following psychodiagnostic techniques: drugs "," Scale of structured interview to determine the attitude of family members to the disease (psychiatric diagnosis) in a relative. "

Results: according to the method "Type of family attitude to therapy with psychotropic drugs": supporting type $-13.13 \%$, detached type $-18.03 \%$ of families, hostile type was in $31.14 \%$ of families, manipulative type $-37.70 \%$. According to the method "Scale of structured interview to determine the attitude of family members to the disease (psychiatric diagnosis) in a relative" we received $34.42 \%$ with a dramatizing attitude to the disease, $13.13 \%$ of families with an adequate attitude to the disease of a loved one and $52.45 \%$ with a destructive attitude to the disease.

Conclusions: The data we obtained cover a very difficult situation in families with dementia, in the future our work will be aimed at establishing a balance in the families of patients with dementia, which in turn will improve the existence of this cohort. 


\section{References:}

[1] Shevchenko-Bitenskyi, K. V. (2019). Sotsialne funktsionuvannia patsiientiv z haliutsynatorno-paranoidnymy rozladamy pry zmishanykh dementsiiakh tiazhkoho stupenia vyrazhenosti [Social functioning of patients with hallucinatory-paranoid disorders in mixed dementia of severe severity]. Ukrainskyi visnyk psykhonevrolohii, (27, 3 / 100), 61-64.

[2] Pinchuk, I. Ya., Kolodiezhnyi, O. V., Drevitska, O. O., Myshakivska, O. M., Zdoryk, I. F. (2017). Psykhiatrychni tsentry dennoho dohliadu - Perspektyvnyi napriam rozvytku psykhiatrychnoi dopomohy [Psychiatric Day Care Centers - A Prospective Area for the Development of Psychiatric Care]. Arkhiv psykhiatrii, (23, 1 / 88), 74-75. 


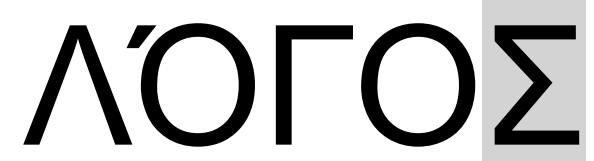

COLLECTION DE PAPIERS SCIENTIFIQUES

SUR LES MATÉRIAUX DE LA CONFÉRENCE SCIENTIFIQUE ET PRATIQUE INTERNATIONALE

«TENDANCES SCIENTIFIQUES DE LA RECHERCHE FONDAMENTALE ET APPLIQUÉE»

30 octobre 2020 • Strasbourg, République française

\author{
VOLUME 2
}

\begin{abstract}
Ukrainien, russe, français et anglais
Les matériaux sont imprimés dans le texte de l'auteur Le comité organisateur ne partage pas toujours la position des auteurs Pour l'exactitude de ce matériel, les auteurs portent la responsabilité
\end{abstract}

Signé pour impression le 30.10.2020. Format 60×84/16.

Papier offset. Arial type. Impression numérique

Feuilles imprimées conditionnées 7,56.

Un tirage de 100 exemplaires.

Imprimé à partir de la mise en page originale finie.

Coordonnées du comité d'organisation:

21037, Ukraine, Vinnytsia, st. Zodchih, 18, bureau 81

Plateforme scientifique européenne

Téléphones: +38 098 1948380; +380981956755

E-mail: info@ukrlogos.in.ua

URL: www.ukrlogos.in.ua 